RESEARCH NOTE

\title{
Use of atypical aquatic breeding habitat by the California tiger salamander
}

\author{
JEFF A. ALVAREZ ${ }^{*}$, MARY A. SHEA ${ }^{2}$, SARAH M. FOSTER $^{3}$, \\ AND JEFFERY T. WILCOX ${ }^{4}$
}

${ }^{1}$ The Wildlife Project, P.O. Box 188888, Sacramento, CA 95818

${ }^{2} 1143$ Second Street, Suite A-172, Brentwood, CA 94513

${ }^{3}$ Foster Wildife Surveys, $7745^{\text {th }}$ Ave, Sacramento, CA 94818

${ }^{4}$ Sonoma Mountain Ranch Preservation Foundation, Petaluma, CA, 94954

*Corresponding Author: jeff@thewildlifeproject.com

Key words: aquatic, atypical, breeding, Ambystoma californiense, eggs, habitat, plasticity, sites, threatened

The California tiger salamander (Ambystoma californiense) has been a species of focused study due to habitat loss and population declines. The species is state and federally listed as either threatened or endangered throughout its entire range in California (USFWS $2000,2002,2004)$. Ambystoma californiense has historically been closely associated with its putative breeding habitat in lentic waters, in particular, vernal pools - typically shallow, rain-filled water bodies with hydroperiods that last up to several months (Storer 1925; Fitzpatrick and Shaffer 2004; Lannoo 2005). Several investigators have suggested that the decline of the species is related to declines in vernal pools throughout the species' range (Stebbins and Cohen 1995; Loredo and Van Vuren 1996; Fitzpatrick and Shaffer 2004). However, there is an increased understanding of the ability of $A$. californiense to frequently use perennial waterbodies and seasonal cattle stock ponds as aquatic breeding habitat, which may ultimately contribute to the conservation of the species (Alvarez 2004a,b; Wang et al. 2009; Wilcox et al. 2015). Here we report on observations of additional breeding site plasticity in A. californiense which were found breeding in atypical habitats, such as perennial creeks and anthropogenic structures.

We conducted opportunistic visual encounter surveys, often while conducting other watershed management activities, and observed $A$. californiense using perennial or nearly perennial sections of three creeks in eastern Contra Costa County, CA. During two reproductive seasons separated by 12 years (i.e., 1996 and 2008), approximately 30-40 A. californiense adults and thousands of eggs were observed in Brushy Creek (a fishless creek approximately $3.5 \mathrm{~m}$ wide and $1 \mathrm{~m}$ deep; Fig. 1a). This site included a seasonally flowing, intermittent creek with a silt bottom that slowly flowed through level ground within open 
annual grasslands. Vegetation consisted of live and decadent non-native annual grasses and scattered clumps of Juncus balticus. The nearest known breeding location of $A$. californiense to this location was a seasonal stock pond approximately $300 \mathrm{~m}$ west of Brushy Creek. In 2010, approximately 10 A. californiense eggs were detected in Kellogg Creek, an adjacent watershed (approximately $5 \mathrm{~m}$ wide and $2 \mathrm{~m}$ deep; Fig. 1b). This site included a perennial creek with a silt bottom that was bordered by valley oaks (Quercus lobata), Fremont cottonwood (Populus fremontii), and willow (Salix spp.), and included emergent patches of Typha latifolia. It flowed very slowly, meandering through level ground among low hills covered by annual grasslands. Kellogg Creek is hydrologically connected to the Sacramento-San Joaquin River Delta and supports numerous species of fishes from the families: Cottidae, Cyprinidae, and Centrachidae, as well as Sacramento sucker (Catostomus occidentalis). The nearest known breeding location of $A$. californiense to this location was a perennial stock pond, approximately 710 m northwest of Kellogg Creek. At a third site, approximately 25-100 A. californiense larvae (ranged in number depending upon year) ( $\leq$ $75 \mathrm{~mm}$ TL) were observed from 2001-2012 inhabiting a nearly perennial (i.e., wet through mid to late-summer), fishless pool within an unnamed tributary of Kellogg Creek (Fig. 1c). This site consisted of a seasonal, rain-filled pool (35 m x $3 \mathrm{~m}$ and $0.5 \mathrm{~m}$ deep) with a firm clay bottom that was bordered by live and decadent non-native annual grasses and scattered clumps of Juncus balticus. Generally, there was no flow within this pool, but it was hydrologically connected to Kellogg Creek during peak inundation (i.e., during rain events). The nearest known breeding location of $A$. californiense to this site was a perennial stock pond, approximately $630 \mathrm{~m}$ northwest of Kellogg Creek.

In 2000, also in eastern Contra Costa County, we had single season observations of adult $A$. californiense breeding in two long-lived rain-filled depressions ( $1 \mathrm{~m}$ x $3 \mathrm{~m}, 1 \mathrm{~m}$ deep) created from soil excavation at a construction site. This steep-sided excavation supported standing-water for approximately 2 months and was located $330 \mathrm{~m}$ north of a known breeding location for A. californiense. Similarly, in 2010, A. californiense were observed breeding in a rain-filled pool created by soil compaction surrounding a horse trough. This pool was approximately $5 \mathrm{~m} \times 5 \mathrm{~m} \times 0.3 \mathrm{~m}$ deep, with a $2 \mathrm{~m}$ circular horse trough at its center. The nearest known breeding location of $A$. californiense to this location was an seasonal stock pond, approximately $640 \mathrm{~m}$ to the east. Larvae were noted in both pools during subsequent visits to these individual sites, but no attempt was made to determine if metamorphosis occurred.

During the springs of 2008, 2011, 2018 and 2019, in eastern Santa Clara County on the Blue Oak Ranch Reserve, > 100 A. californiense eggs were observed during each visit in a partially buried concrete trough ( $3 \mathrm{~m} \mathrm{x} 1 \mathrm{~m}, 0.5 \mathrm{~m}$ deep; Fig. 1d). The nearest known breeding location of $A$. californiense to this perennial water body was a perennial stock pond, approximately $240 \mathrm{~m}$ west. During three of the four years, we observed $A$. californiense larvae among dense algal growth and debris within the trough. A. californiense were able to access the trough directly due to the trough being buried to soil level on three sides, however it is unknown whether these larvae metamorphosed and/or were able to leave the trough. A small piece of hardware cloth was placed in the trough in 2012 to facilitate self-escape by newly metamorphosed individuals.

Although it is likely that some of these rain-filled seasonal aquatic breeding sites (e.g., inundated excavation, horse trough depression) dried prior to the metamorphosis of A. californiense larvae, clearly such features attract adults, which use them as ovipositing sites. Some of these observations occurred in habitat that was reported to be perennial, or 

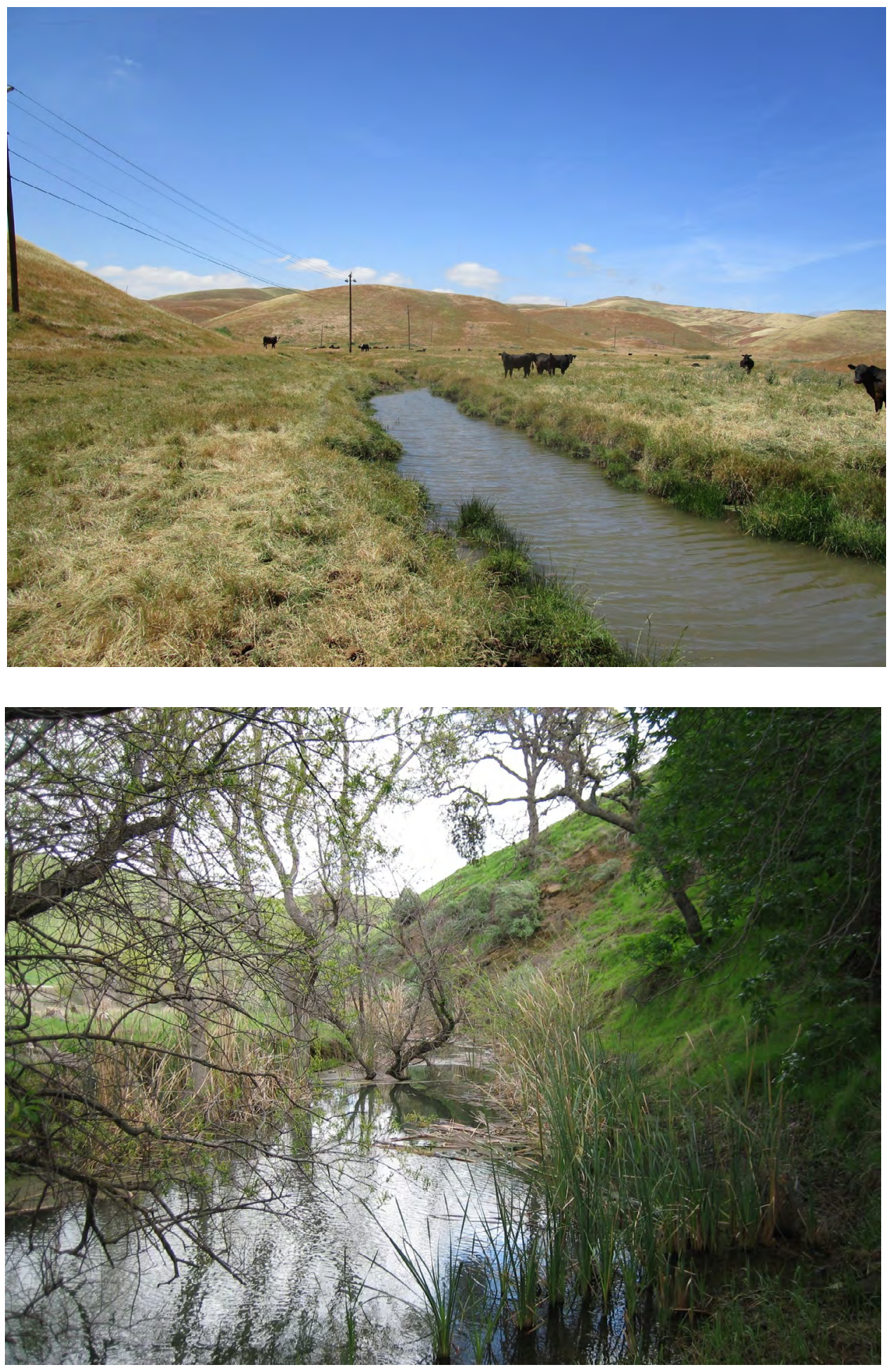

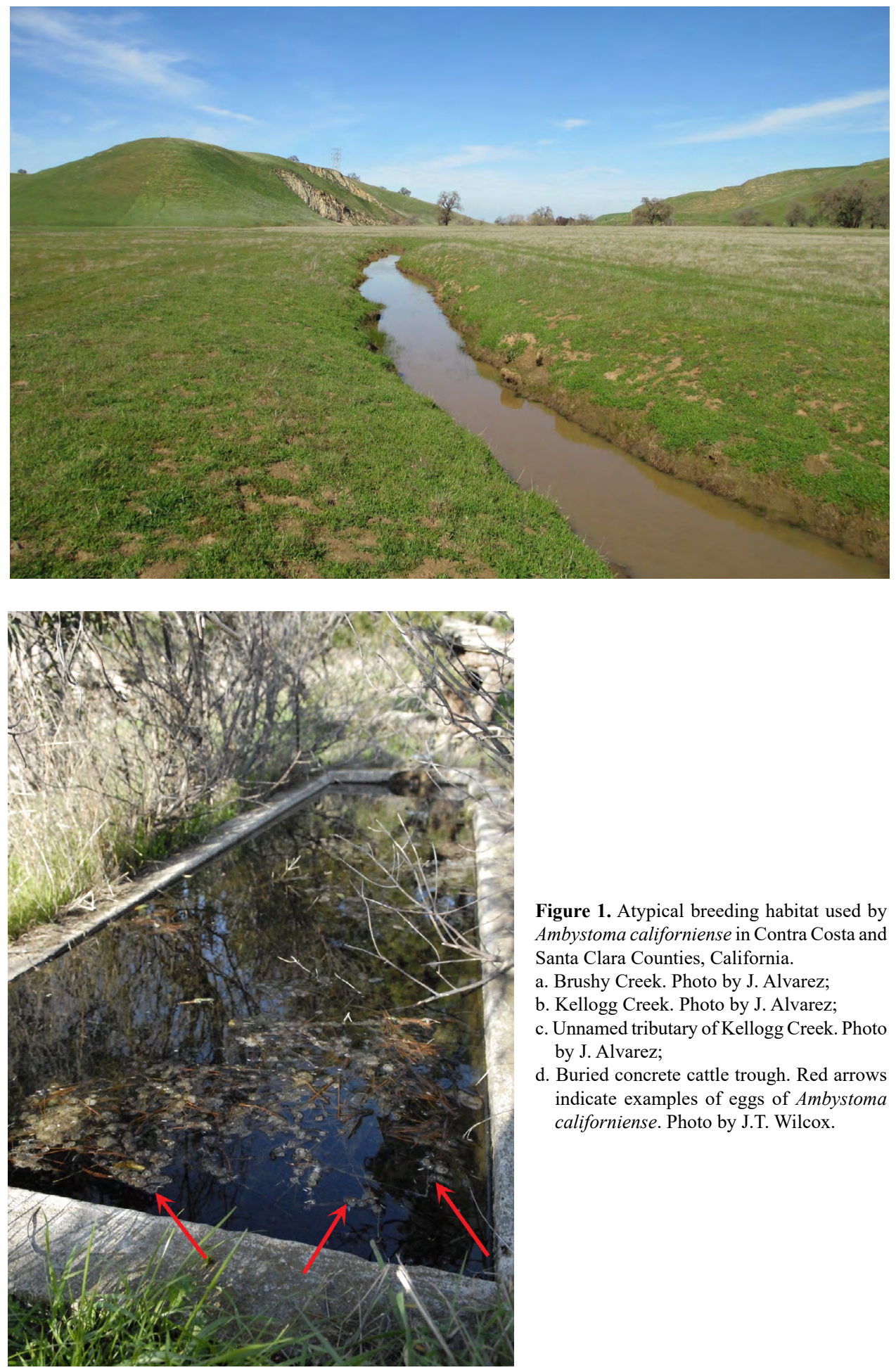

Figure 1. Atypical breeding habitat used by Ambystoma californiense in Contra Costa and Santa Clara Counties, California.

a. Brushy Creek. Photo by J. Alvarez;

b. Kellogg Creek. Photo by J. Alvarez;

c. Unnamed tributary of Kellogg Creek. Photo by J. Alvarez;

d. Buried concrete cattle trough. Red arrows indicate examples of eggs of Ambystoma californiense. Photo by J.T. Wilcox. 
nearly so (i.e., Brushy Creek, Kellogg Creek, and an unnamed tributary), which may have facilitated successful metamorphosis in some years.

Storer (1925) reported collecting eggs of $A$. californiense from pools that formed in "ephemeral drainages" in the foothills of the Sierra Nevada range. Storer's report of the use of lenitc sections of a lotic system would be consistent with the general types of observations we made. The observations reported here, including A. californiense breeding in newly created sites, suggests that some $A$. californiense breed in pools that are encountered opportunistically. The reported use of a large variety of aquatic breeding habitat (i.e., vernal pools, stock ponds, intermittent creeks, fishless perennial creeks, and temporary pools) supports our contention. Opportunistic use of available aquatic breeding habitat could facilitate colonization of new sites, making it possible for long-term persistence in areas with few or no vernal pools, or where large-scale habitat changes have occurred. Alternatively, $A$. californiense utilizing these atypical breeding sites, in some years, may experience a reproductive sink - reproduction occurs, larvae hatch, but no metamorphosis occurs due to limited hydroperiod, inability to self-escape (i.e., concrete trough or step-sided excavations), or direct impact (i.e., trampling by horses using horse trough).

Ambystoma californiense is a species in decline and continues to be adversely affected by modification and/or loss of aquatic breeding habitat. Although we do not suggest that fishless intermittent or perennial creeks could be a reasonable long-term aquatic breeding site surrogate, we believe that a landscape-scale understanding of all potential $A$. californiense habitat use, including atypical breeding habitats, is critical for conducting complete site assessments for this species. More specifically, within upland habitat that includes a mix of vernal pools, stock ponds, creeks, and other potential aquatic breeding sites, long-term persistence of $A$. californiense may rely on the availability of all of these habitat types, including the use of sites previously characterized as atypical. Reproductive site plasticity may play a role in population persistence through climactic changes, stochastic events, and adjacent habitat alterations. Therefore, use of these atypical sites as potential breeding habitat for A. californiense should be considered during site assessments and other regulatory actions.

\section{ACKNOWLEDGEMENTS}

The Contra Costa Water District and the Blue Oak Ranch Preserve, University of California, Berkeley, California, provided access to these sites. We are very grateful to N. Parizeau for editorial assistance and helpful contributions to the manuscript. Four anonymous reviewers offered extremely helpful and constructive suggestions that greatly improved the manuscript.

\section{LITERATURE CITED}

Alvarez, J. A. 2004a. Use of artificial egg-laying substrate to detect California tiger salamanders (Ambystoma californiense). Herpetological Review 35:45-46.

Alvarez, J. A. 2004b. Overwintering California tiger salamander (Ambystoma californiense) larvae. Herpetological Review 35:344.

Fitzpatrick, B. M., and H. B. Shaffer. 2004. Environment-dependent admixture dynamics in a tiger salamander hybrid zone. Evolution 58:1282-1293.

Lannoo, M. 2005. Amphibian Declines, University of California Press, Berkeley, CA, USA. 
Loredo, I., and D. Van Vuren. 1996. Reproductive ecology of a population of the California tiger salamander. Copeia 1996:895-901.

Stebbins, R. C., and N. W. Cohen. 1995. A Natural History of Amphibians. Princeton University Press, Princeton, NJ, USA.

Storer, T. 1925. A synopsis of the amphibia of California. University of California Publications in Zoology 27:1-342.

U.S. Fish and Wildlife Service (USFWS). 2000. Federal Register 65:57242-57264.

U.S. Fish and Wildlife Service (USFWS). 2002. Endangered and threatened wildlife and plants; listing the Sonoma County distinct population segment of the California tiger salamander. Federal Register 67:47726-47740.

U.S. Fish and Wildlife Service (USFWS). 2004. Endangered and threatened wildlife and plants; determination of threatened status for the California tiger salamander; and special rule exemption for existing ranching activities. Federal Register 69:47212-47248.

Wang I. J., W. K. Savage, and H. B. Shaffer. 2009. Landscape genetics and least-cost path analysis reveals unexpected dispersal routes in the California tiger salamander ( $\mathrm{Am}$ bystoma californiense). Molecular Ecology 18:1365-1374.

Wilcox, J. T., G. E. Padgett-Flohr, J. A. Alvarez, and J. R. Johnson. 2015. Possible phenotypic influence of superinvasive alleles on larval tiger salamanders (Ambystoma californiense). American Midland Naturalist 173:168-175.

Submitted 30 September 2020

Accepted 2 November 2020

Associate Editor was D. Applebee 